University of New Hampshire

University of New Hampshire Scholars' Repository

Law Faculty Scholarship

University of New Hampshire - Franklin Pierce

School of Law

$1-1-2010$

\title{
Intellectual Property, Medicine and Health: Current debates
}

Stanley P. Kowalski

University of New Hampshire School of Law, stanley.kowalski@law.unh.edu

Follow this and additional works at: https://scholars.unh.edu/law_facpub

Part of the Intellectual Property Law Commons, and the Medicine and Health Sciences Commons

\section{Comments}

This paper was published in the Journal of Commercial Biotechnology at http://CommercialBiotechnology.com,

http://perma.cc/WS75-RDWA

\section{Recommended Citation}

Stanley P. Kowalski, "Intellectual Property, Medicine and Health: Current debates," $16 \mathrm{~J}$. of Comm. Biotech., 191 (2010) (book review).

This Book Review is brought to you for free and open access by the University of New Hampshire - Franklin Pierce School of Law at University of New Hampshire Scholars' Repository. It has been accepted for inclusion in Law Faculty Scholarship by an authorized administrator of University of New Hampshire Scholars' Repository. For more information, please contact sue.zago@law.unh.edu. 


\title{
Book Review
}

\section{Intellectual property, medicine and health: Current debates}

\section{Johanna Gibson}

\begin{abstract}
Ashgate, Farnham, England and Burlington, VT, USA, 2009, hardback, 223pp., £55.00, ISBN: 978-0754672180
\end{abstract}

Journal of Commercial Biotechnology (2010) 16, 191-193. doi:10.1057/jcb.2009.40;

published online 26 January 2010

Recent discussions regarding global access to innovations in health in developing countries have focused on intellectual property rights (IPR). ${ }^{1}$ For example, IPR are embedded at each stage of vaccine development and access, including research (laboratory and clinical programs), appropriate regulations to ensure safety and efficacy, manufacturing capabilities to meet international quality standards, licensing and international procurement. ${ }^{2}$ Indeed, although not the sole factor affecting access, IPR nevertheless are ubiquitous and important. ${ }^{3}$ Management of IPR can be advanced via dynamic linkages, for example, public-private partnerships such as the International AIDS Vaccine Initiative. ${ }^{4}$ Hence, IPR can be an impediment (restricting access) or an opportunity (creating linkages) depending on how they are managed.

Johanna Gibson's Intellectual Property, Medicine and Health: Current Debates is an ambitious attempt to bridge the gap between IPR (largely patents) and the ethical, moral and philosophical issues which should influence global access to innovations in health.

This intent is noteworthy and timely, as the complexities are important to address and there is an urgent need for clear-headed strategy. However, disappointingly, the book largely fails, as it is a rambling polemic that lacks focus, clarity and originality. Wading through the thicket of verbiage becomes so daunting that whatever message might be present is lost. The book also is flawed in its skewed interpretation of IP law and lack of forward vision. As such, it mostly stands as a rehashing of previous material, adding little in the way of new analyses or suggested strategic options.

The 223-page book is divided into four sections: (1) Health: the life of health, the health of intellectual property; (2) Rights: the human right to health, health development and culture, patent morality; (3) Life: the technology of life, life's libraries; (4) Access: access, use. Each of these sections then expands on the topic; for example 'rights' are further discussed as the right to selfdetermination, right to access to medicine and the right to benefit from one's creativity. The author then juxtaposes these rights with IPR, drawing conclusions and making inferences about developing countries' access to innovations in health that might be true under certain circumstances, yet are largely skewed toward the presumed injustice of the global system of IPR, that is, how the North has weaponized IPR to further dominate the South. The author's citing of notoriously 
anti-IPR organizations, for example, RAFI (p. 129) and Greenpeace (p. 107), as authoritative, credible sources, further exacerbates this advocacy.

The book's messages are often lost in a densely entangled mass of nearly incomprehensible prose. In addition, there is an annoying overuse of jargon (for example, 'arguably' and 'articulated'), as if the spoken word had been directly dictated to text, with little or no independent editorial oversight in later drafts of the manuscript (assuming there actually were later drafts). Verbosity abounds, for example: 'In other words, in place is a strict division between the material and objective nature of the intellectual property system with the subjectivity of moral rights rendered peripheral to the organic unity of that system. Thus, the social and legitimate agency of the actors within that system is deferred by the priority attached to the economic modeling of innovation and creativity' (p. 11). Wordiness is further coagulated by throat-clearing slang: 'Significantly, a cultural interrogation of the patent system precipitates recognition of the critical value of access to the intention of the system. Arguably, this access value is articulated through the concept of use within the patent framework' (p. 22) (italic emphasis added by reviewer). For subsequent works, it might be advisable to consult Strunk and White for guidance on concise writing. ${ }^{5}$

Confusing legal discussion also appears. For example: 'Therefore, although it is beyond the remit of an economic system of regulation to fulfill the ethical oversight of these fields of technology, the patent system features in the moral dilemma of biotechnology inventions. Arguably, although often described to the contrary, it is not the ownership as such but the authorship that is the critical antagonist in these debates' (p. 13) (italic emphasis added by reviewer). Patents have inventors, not authors. Authors are for copyrighted works, for example, books. This is the same legally operative terminology in both US and UK patent law as well as the European Patent Office.
Another example further illustrates the confused tone of the legal discussion: 'The market is achieved by imposing certain monopoly rights with respect to use, thus achieving an artificial scarcity on certain manifestations (fixations) of information' (p. 24) (italic emphasis added by reviewer). There are two problems with this statement. First, patents are not monopolies per se. Patents neither automatically confer market domination nor establish a cartel. To assert that patents confer monopolistic power defies logic, as they protect inventions that are, by definition, new and hence cannot be 'scarce' as they are novel in the first instance. Patents simply confer property rights, albeit intangible. As per McCarthy: 'Without a rigorous analysis and definition of the relevant economic market, one cannot say that the claims of all, or even many, patents define a substantial portion of a true relevant market'. ${ }^{6}$ Puzzlingly, the book also has a section (p. 188) that addresses patent pools, and again uses the term 'monopoly' ('Therefore, a patent pool can also create a monopoly over certain technology if competitors cooperate ...'), yet fails to distinguish that use of the term from its ubiquitous (mis)use throughout the book. The second problem with the statement above is, once again, the confusion of copyright with patent terminology: 'fixations of information' are copyrighted (inventions are patented).

On page 115, US5567607 is incorrectly cited as the original patent on the Harvard Oncomouse. US5567607, a patent covering a method for producing transgenic animals, is assigned to Incel, was granted in 1996 and is not connected via patent prosecution (nor even citation) to the original Oncomouse patent. The issue is further confused by the assertion that this method would cover the mice themselves (presumably as compositions of matter), which is wrong: it would only cover the method. However, the error is truly glaring in that the correct original patent for Oncomice is US4736866 (inventors are Leder and Stewart; assignee is Harvard), 
licensing, differential pricing and similar aid mechanisms. This perpetuates the notion that the hapless South will forever require assistance, always need to be rescued by well-meaning intellectuals of the North, and fosters a failed development agenda that stresses 'special' assistance in lieu of solid, sustainable global partnerships.

\section{REFERENCES}

1. Krattiger, A. et al (2007) Executive Guide to Intellectual Property Management in Health and Agricultural Innovation: A Handbook of Best Practices. Oxford, UK; Davis, CA; Rio de Janeiro, Brazil; and Ithaca, NY: MIHR, PIPRA, Oswaldo Cruz Foundation and bioDevelopments-International Institute, http://www.ipHandbook.org.

2. Mahoney, R.T., Krattiger, A., Clemens, J.D. and Curtiss III, R. (2007) The introduction of new vaccines into developing countries IV: Global access strategies. Vaccine 25(20): 4003-4011.

3. Eiss, R., Hanna, K.E. and Mahoney, R.T. (2007) Ensuring global access through effective IP management: Strategies of product-development partnerships. In: A. Krattiger, R.T. Mahoney, L. Nelsen, J.A. Thomson, A.B. Bennett, K Satyanarayana, G.D. Graff, C. Fernandez and S.P. Kowalski (eds.) Intellectual Property in Health and Agricultural Innovation: A Handbook of Best Practices. Oxford, UK; Davis, CA: MIHR and PIPRA, pp. 63-78, http://www.iphandbook.org.

4. Hanlin, R., Chataway, J. and Smith, J. (2007) Global health public-private partnerships: IAVI, partnerships and capacity building. African Journal of Medicine and Medical Sciences 36: S69-S75.

5. Strunk Jr, W. and White, E.B. (1999) The Elements of Style, 4th edn. New York: Longman Publishers.

6. McCarthy, J.T., Schechter, R.E. and Franklyn, D.J. (eds.) (2004) McCarthy's Desk Encyclopedia of Intellectual Property, 3rd edn. Arlington, VA: BNA Books.

7. Hanahan, D., Wagner, E.F. and Palmiter, R.D. (2007) The origins of oncomice: A history of the first transgenic mice genetically engineered to develop cancer. Genes \& Development 21: 2258-2270.

8. Moyo, D. (2009) Dead Aid: Why Aid Is Not Working and How There Is a Better Way for Africa. New York: Farrar, Straus and Giroux.

Stanley P. Kowalski Franklin Pierce Law Center, International Technology Transfer Institute, Concord, NH, USA 